\title{
Diversity and Socio-Economic Value of Wild Edible Plants in the Mounts Mandara Region, Cameroon
}

\author{
Froumsia Moksia ${ }^{1}$, Hamawa Yougouda ${ }^{2}$, Nanga Jeanne Flore ${ }^{1}$, \\ Souare Konsala ${ }^{1}$, Tchobsala ${ }^{1}$, Dibong Siegfried Didier ${ }^{3}$, \\ Zapfack Louis ${ }^{4}$, Mapongmetsem Pierre Marie ${ }^{5}$
}

\begin{abstract}
${ }^{1}$ Department of Biological Sciences, Faculty of Science, University of Maroua; P.O Box 814 Maroua, Cameroon
${ }^{2}$ Department of Agriculture, Breeding and Derived Products, National Advanced School of

Engineering, University of Maroua, P. O Box 46 Maroua, Cameroon

${ }^{3}$ Department of Botany, Faculty of Science, University of Douala; P.O Box 24157 Douala, Cameroon

${ }^{4}$ Department of plants Biology, Faculty of Science, University of Yaounde I; P.O Box 812 Yaoundé, Cameroon

${ }^{5}$ Department of Biological Sciences, Faculty of Science, University of Ngaoundere; P.O Box 454 Ngaoundere, Cameroon
\end{abstract}

\begin{abstract}
A study was carried out in the Mounts Mandara to assess the diversity of edible plant species, to identify the use of the edible products, and to determine their socio-economic value. Interviews of a sampling population were conducted randomly in 5 zones with 5 villages each and in rural and urban markets; a sample of 1020 persons was interviewed to evaluate and quantify the various products and determine their flows. The results showed that the edible plant products used in the area were: fruits, leaves, flowers, seeds, tubers, roots, barks and stems. These products were harvested from 61 plant species belonging to 29 families in which 54 species were fruit trees, 11 species produced leaves and / or flowers, 4 species produced seeds. The total annual quantity of products harvested was $1080.9 \mathrm{t}$ in which: fruit $(725.62 \mathrm{t})$; leaves $(97.5 \mathrm{t})$, flowers $(1.96 \mathrm{t})$, and seeds $(255.82 \mathrm{t})$. The seeds of Parkia biglobosa were the most useful part by the populations of Mounts Mandara making "dawa-dawa" some traditional aromatic for a sauce. Exploited products were an important source of food and income for the people. Annually, exploited products generated at whole of 60783975 F CFA. The fruits were sold for 17542375 F CFA, the seeds yielded $36676900 \mathrm{~F} \mathrm{CFA}$, the contribution of the leaves was $5452820 \mathrm{~F}$ CFA and that of the flowers was 724880 F CFA, "dawa-dawa" brought, very popular, bring in a modest sum of $787000 \mathrm{~F} \mathrm{CFA}$. Local people were developing interest in exploiting different bush products. The exploitation activities of the various products were intensifying; the requested species must be domestication to ensure the sustainable management.
\end{abstract}

Keywords: Plants Products, Income, Sustainability, Mounts Mandara, Cameroon

\begin{abstract}
Introduction
In the sub-Saharan African countries, most of the populations lives in the rural zones and are characterized by an ambient poverty. This population is confronted to the insufficiency of the agricultural production to satisfy their daily requirement out of food and to ensure their well been. To resolve this problem, the rural populations have developed particular interest on wild plants products which are exploited for foods, heath, and income (Ambé, 2001 ; Mapongmetsem et al., 2008; Dieng, 2017). Important natural resources exploited in forests and on which rural people depend are non-timber forest products (Laporte and Justice 2001, Biloso 2008, Malela 2016). Non-timber forest products refer to biological resources other than timber and industry
\end{abstract}

that are harvested from natural or man-made forests (Aubé 1996, Peters 1997). In plants, they include various organs such as: leaves, stems, bark, roots, bulbs, rhizomes, tubers, fruits and seeds, edible fungi (Tabuna, 1999). They provide rural populations with the products they need to survive (Ndoye and Perez 1998, Tabuna 2000). These resources contribute to supplementing the food intake of the rural populations (Maydell, 1990, Donfack, 1998). Nontimber forest products, given their diversity and variability in quantity and quality, are of great ecological and socio-economic importance (Neumann and Hirsch 2000, Belcher 2003, Biloso and Lejoly 2006, Biloso 2008). Various plant organs are consumed and marketed in local, national, regional and international markets (El-Siddig et al., 2006,

This article is published under the terms of the Creative Commons Attribution License 4.0

Author(s) retain the copyright of this article. Publication rights with Alkhaer Publications.

Published at: http://www.ijsciences.com/pub/issue/2019-10/

DOI: 10.18483/ijSci.2168; Online ISSN: 2305-3925; Print ISSN: 2410-4477 
Mbaye, 2006, Aboubakar et al., 2009, Bourou et al., 2010, Kouebou et al., 2013, Dieng, 2017). The collection, processing and sale of these non-timber forest products thus enable rural populations to earn income enabling them to buy manufactured products and production tools (Apema et al., 2010; Biloso, 2008; Ayeni et al., 2003).

In the Sudano-Sahelian zone of Cameroon, vegetation is poorly diversified and severely degraded due to significant anthropogenic activities and climatic hazards, and the level of logging has exceeded the increase in woody biomass (Letouzey 1985, Mvondo 2002). Deforestation leads to an impoverishment of the original flora and a decrease in soil fertility. The exploitation of non-timber forest products in the woodland is heavily practiced by local populations for family consumption and some is marketed. As such, it is imperative to inventory the various edible plant products used in the area and know their socio-economic importance, in order to develop appropriate strategies for sustainable management.

The present study generally aims to determine the diversity of edible plant species and their socioeconomic value for sustainable management. More specifically to:

- acknowledge the edible plant species exploited and their consumed parts;

- evaluate the quality and the quantity of the edible products exploited and;
- determine the socio-economic value of the edible plant products.

\section{Material and methods \\ Study area}

Investigations were carried out in the Mount Mandara located between $10^{\circ} 45^{\prime} 0$ " North and $13^{\circ} 40^{\prime} 0$ " East. In the administrative plan, it covers two regions: North and Far- North and extending on 4 divisions (Mayo-Sava, Diamaré, Mayo-Tsanaga in the FarNorth region and Mayo-Louti in the North region (Figure 1). The climate of the Mount Mandara was characterizedby the Sudano-Sahelian type and modified by the orogenic effects. Two varieties were known: in the North, the climate was SaheloSudanian type with a period of four months of rainfall, and in the South, the sudano sahelian type with a periode of five months of rainfall. The annual average rainfall was about $800 \mathrm{~mm}$ in the Northern part and $1100 \mathrm{~mm}$ in the Southern part. The temperatures oscillated between $13^{\circ} \mathrm{C}$ (January) and $38^{\circ} \mathrm{C}$ (April); the annual average temperature was $28^{\circ} \mathrm{C}$. This vegetation was strongly degraded under the pressure of the anthropogenic actions (cutting for firewood, charcoal, wood service, bush fires and overgrazing) and the climatic threat (Letouzey, 1985; Westphal et al., 1985). The economic activities of the zone were based on extensive agriculture subsistence, extensive breeding, and exploitation of resources, craft industry and the small trade. The exploitation of firewood, the non-timber forests products and charcoal, constituted a significant generating activity of substantial income for the poor rural families. 


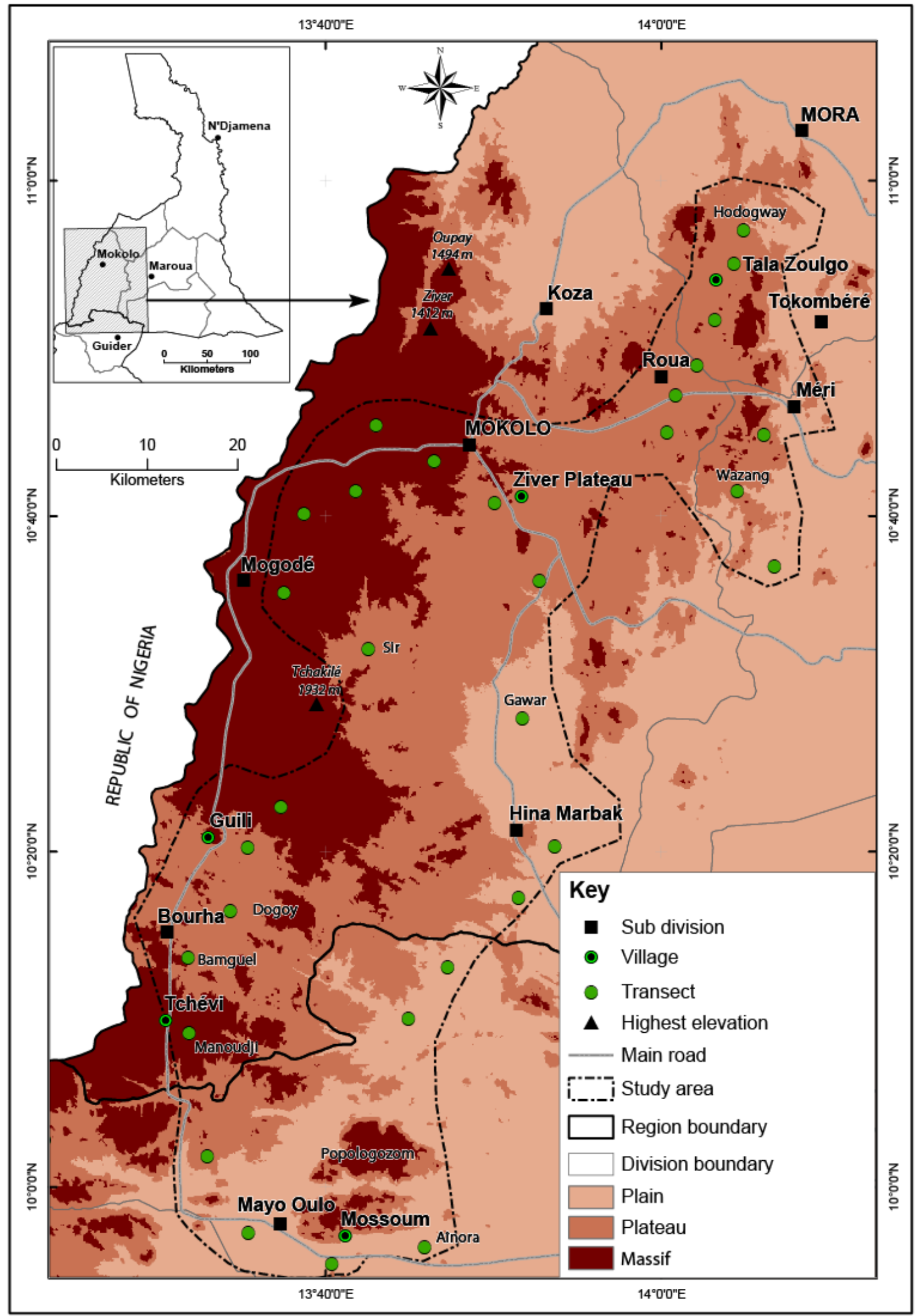

Figure 1 : Study area in the Mount Mandara. 


\section{Data collection}

To carry out this study, 40 villages were selected along the Mandara Mountains chains, according to the criteria of accessibility, attendance of edible plant exploitation activities, demographic and the presence of some ethnic groups. These villages were gathered in 5 zones as follows: Mokolo; Roua-Plateau Zoulgo; Bourha-Plateau Kapsiki; Hina-Guider; Méri. The investigations were also conducted in 35 rural markets and 8 urban markets in which exploited products were sale. A sample of 1020 people, whose age was between 15 and 60 years, was divided in 486 men and 534 women were interviewed. This interview targeted on: women, the main actors in the use of plant products and recovery; children, actors collecting and picking fruits and, old men who were the holders of information relating to evolution and history of lands. The data were collected during semistructured talks and of the talks focused on the topics related to the exploitable natural resources. The semidirect interviews (individual and group) were carried out using an interviews guide and targeted people who had practiced at least once an activity of exploitation and / or marketing of edible plants in the Mandara Mountains. The interview guide included the following topics: knowledge of edible plant species and their uses, consumed parts, their availability, the qualities and quantities of the products collected the mode of exploitation, collection periods, their socio-economic importance, commercialized edible species, marketed parts, prices and places of sale of the product and, the income generated.

The evaluation and quantification of products with high socio-economic value was made with stakeholders at various levels (collectors, wholesalers, retailers and consumers). To quantify and follow the exchanges of the products, a register was given to the collectors having accepted the collaboration. The investigating officers visit the operators once a month to update the register on all the information concerning the transactions of the exploited products. In this register were noted: the products exploited, the quantities harvested, those consumed, sold and offered, the quantities processed and the final product, the units of sale and the prices on the markets, the income generated, the constraints related to the exercise of the activity. Quantification was done using a Roberval type weighing scale, capacity $50 \mathrm{~kg}$ and the unit of measurement for all products was $\mathrm{kg}$. For each non-timber forest product collected, the contents of the units of measurement used for sale were weighed 10 times to determine the average weight.

\section{Results \\ Edible plant products exploited in the Mounts Mandara}

In the Mount Mandara region, there was enumerated various edible wild plant products exploited as far as fruits, leaves, flowers, seeds, tubers, barks, roots. These products were eaten fresh or dried, raw or processed. (Table I). A whole of 61 edible plant species belonging to 29 families were identified; among them, 54 species were spontaneous fruits which were exploited for consumption and marketed by the populations. The most popular fruit species in the mounts Mandara were: Ziziphus mauritiana (93.28\%), Tamarindus indica (90.25\%), Diospyros mespiliformis (87.56\%), Parkia biglobosa (86.27\%), Adansonia digitata (76.84\%), Ximenia americana (63.27\%), Carissa edulis (57.36\%), Vitex doniana $(48,27 \%)$, Haematostaphis barteri (47.36\%), Annona senegalensis (57.36 \%), Detarium microcarpum (45.27\%), Ziziphus spina-christi (57.29 $\%)$ and, Sarcocephalus latifolius (56.17\%). The various fruits were an important source of food for the people. The consumption contributed to reduce the number of daily meals and the left over products was commercialized to provide a substantial income to the local populations. Some was conserved and was used as food supplement during the food lack period. Only 4 species (Parkia biglobosa (95.54\%), Balanites aegyptiaca (33.21\%), Sclerocarya birrea $(28.35 \%)$, and Vitellaria paradoxa $(24.23 \%)$ ) were identified with seeds exploited for consumption, oil extraction (Table 1). The seeds of Parkia biglobosa were the most useful part by the populations in the Mount Mandara region making "dawa-dawa" some traditional aromatic for a sauce. Those of Balanites aegyptiaca, locally called "Pouyadi", undergo a treatment to make them edible. The stone of Vitellaria paradoxa were used for the extraction of butter. Populations exploited 11 species for their leaves in which 4 of them were also for flowers. These were: Adansonia digitata (82.77\%), Celtis integrifolia (78.24\%), Tamarindus indica (77.47\% leaves, $68.57 \%$ flowers), Leptadenia hastata (71.23 $\%$ leaves, $70.12 \%$ flowers), Vernonia amygdalina (43.27\%), Balanites aegyptiaca (42.13\% leaves, $5.15 \%$ flowers), Crateva adansoni (42.17\%), Ficus cordata (38.17\%), Ficus gnaphalocarpa (31.28\%), Bombax costatum (17.54 \%, leaves, $84.67 \%$ flowers), Hymenocardia acida (16.31\%). The most exploited plant species for flowers were: Bombax costatum $(84.67 \%)$ and Tamarindus indica (68.57 $\%)$. These leaves and / or flowers were consumed as vegetables and additives because of their mucilaginous quality. The species exploited for tubers and roots were: Dioscorea dumetorum (31.27 $\%)$, Tacca leontopetaloides (24.25\%), Cochlospermum tinctorium $(8.77 \%)$. These tubers and / or roots had some toxic or irritating characters 
and could not be directly consumed by the populations; they must undergo a particular treatment. The treatment eliminated irritating and / or toxic characteristics. The bark of Grewia mullis and Grewia venusta was dried and used as an additive in the sauce for its mucilaginous quality and the stems of fresh or dry Cadaba farinosa were used to sweeten the porridge. Edible bush products were distributed regularly and periodically throughout the year, which allowed farmers to have at least one additional product for their consumption. There was noted the variability of the various edible plant species in the 5 explored zones. This variability of showed by the calculation of the variance as $\mathrm{p}=0.00017$. The populations of the Mounts Mandara considered these products useful for their marketing value and contribution for the daily meal he poor rural family.

Table 1. Edible plant products exploited by the populations.

\begin{tabular}{|c|c|c|c|c|c|c|}
\hline \multirow{2}{*}{ Specie } & \multirow{2}{*}{ Family } & \multicolumn{5}{|c|}{$\begin{array}{l}\text { Frequency of quotations of the plants edible parts } \\
(\%)\end{array}$} \\
\hline & & Fruit & Leaf & Flower & Seed & $\begin{array}{l}\text { Ro/tub/ } \\
\text { ste/bar }\end{array}$ \\
\hline Adansonia digitata & Bombacaceae & 76.84 & 82.77 & - & - & - \\
\hline Ampelocissus africana & Vitaceae & 15.28 & - & - & - & - \\
\hline Annona senegalensis & Annonaceae & 57.36 & - & - & - & - \\
\hline Balanites aegyptiaca & Balanitaceae & 34.17 & 42.13 & 5.15 & 33.21 & \\
\hline Bombax costatum & Bombacaceae & 5.75 & 17.54 & 84.67 & - & - \\
\hline Borassus aethiopum & Arecaceae & 12.77 & - & - & - & - \\
\hline Bridelia scleroneura & Euphorbiaceae & 7.16 & - & - & - & - \\
\hline Cadaba farinosa & Capparaceae & 26.18 & - & - & - & 22.35 \\
\hline Carissa edulis & Apocynaceae & 58.78 & - & - & - & - \\
\hline Celtis integrifolia & Ulmaceae & 7.11 & 78.24 & - & - & - \\
\hline Cochlospermum tinctorium & Cochlospermaceae & - & - & - & - & 8.77 \\
\hline Crateva adansonii & Capparaceae & - & 42.17 & - & - & - \\
\hline Detarium microcarpum & caesalpiniaceae & 45.27 & - & - & - & - \\
\hline Dioscorea dumetorum. & Dioscoreaceae & - & - & - & - & 31.27 \\
\hline Diospyros mespiliformis & Ebénaceae & 87.56 & - & - & - & - \\
\hline Ficus abutilifolia & Moraceae & 17.74 & - & - & - & - \\
\hline Ficus cordata & Moraceae & 16.81 & 38.17 & - & - & - \\
\hline Ficus gnaphalocarpa & Moraceae & 15.13 & 31.28 & - & - & - \\
\hline Ficus ingens & Moraceae & 17.19 & - & - & - & - \\
\hline Ficus platyphylla & Moraceae & 16.25 & - & - & - & - \\
\hline Ficus polita & Moraceae & 28.16 & - & - & - & - \\
\hline Ficus sur & Moraceae & 27.54 & - & - & - & - \\
\hline Ficus sycomorus & Moraceae & 27.26 & - & - & - & - \\
\hline Ficus thonningi & Moraceae & 25.22 & - & - & - & \\
\hline Ficus trichopoda & Moraceae & 27.07 & - & - & - & - \\
\hline Gardenia aqualla & Rubiaceae & 7.12 & - & - & - & - \\
\hline Gardenia erubesens & Rubiaceae & 6.21 & - & - & - & - \\
\hline Gardenia ternifolia & Rubiaceae & 6.27 & - & - & - & - \\
\hline Grevia mullis & Tiliaceae & - & - & - & - & 37.28 \\
\hline Grewia flavescens & Tiliaceae & 3.21 & - & - & - & - \\
\hline Grewia tenax & Tiliaceae & 37.2 & - & - & - & - \\
\hline
\end{tabular}


Some Groupoids and their Representations by Means of Integer Sequences

\begin{tabular}{|c|c|c|c|c|c|c|}
\hline Grewia venusta & Tiliaceae & - & - & - & - & 38.52 \\
\hline Haematostaphis barteri & Anacardiaceae & 47.36 & - & - & - & - \\
\hline Hexalobus monopetalus & Annonaceae & 27.36 & - & - & - & - \\
\hline Hymenocardia acida & Hyménocardiaceae & 8.27 & 16.31 & & & \\
\hline Hyphaene thebaica & Arecaceae & 13.03 & - & - & - & - \\
\hline Landolphia hirsuta & Apocynaceae & 3.51 & - & - & - & - \\
\hline Lannea acida & Anacardiaceae & 17.64 & - & - & - & - \\
\hline Lannea microcarpa & Anacardiaceae & 14.08 & - & - & - & - \\
\hline Lannea schemperi & Anacardiaceae & 16.24 & - & - & - & - \\
\hline Lannea velutina & Anacardiaceae & 16.27 & - & - & - & - \\
\hline Leptadenia hastata & Asclépiadaceae & 16.37 & 71.23 & 70.12 & - & - \\
\hline Maranthes polyandra & Chrysobalanaceae & 13.21 & - & - & - & - \\
\hline Neocarya macrophylla & Chrysobalanaceae & 12.32 & - & - & - & - \\
\hline Oncoba spinosa & Salicaceae & 28.73 & - & - & - & - \\
\hline parinari curatellifolia & Chrysobalanaceae & 14.24 & - & - & - & - \\
\hline Parkia biglobosa & Mimosaceae & 86.27 & - & - & 95.54 & - \\
\hline Sarcocephalus latifolius & Rubiaceae & 56.17 & - & - & - & - \\
\hline Sclerocarya birrea & Anacardiaceae & 33.14 & - & - & 28.35 & - \\
\hline Strychnos innocua & Loganiaceae & 12.24 & - & - & - & - \\
\hline Strychnos spinosa & Loganiaceae & 11.87 & - & - & - & - \\
\hline Tacca leontopetaloides & Taccaceae & - & - & - & - & 27.25 \\
\hline Tamarindus indica & Caesalpiniaceae & 90.25 & 77.47 & 68.57 & - & - \\
\hline Uvaria chamae & Annonaceae & 7.21 & - & - & - & - \\
\hline Vernonia amygdalina & Asteraceae, & - & 43,27 & - & - & - \\
\hline Vitellaria paradoxa & Sapotaceae & 37.24 & - & - & 24.23 & - \\
\hline Vitex doniana & Verbénaceae & 48.27 & - & - & - & - \\
\hline Vitex madiensis & Verbénaceae & 35.21 & - & - & - & - \\
\hline Ximenia americana & Olacaceae & 63.27 & - & - & - & - \\
\hline Ziziphus mauritiana & Rhamnaceae & 93.28 & - & - & - & - \\
\hline Ziziphus spina-christi & Rhamnaceae & 57.29 & - & - & - & - \\
\hline
\end{tabular}

The mode of exploitation of the products varied with the type of organ to be sampled and the species: Fruit, leaves, flowers, seeds, tubers, bark and roots. The various collection methods were: the gathering (81.30\%), pruning, trimming, felling down trees $(17.53 \%)$, and debarking and digging $(1.17 \%)$. The main owners were women $(57.81 \%)$, children $(28.73$ $\%)$ and men $(13.46 \%)$. The harvesting of leaves and flowers was mainly the activities of women who were helped by children. The method of harvesting leaves and flowers by felling down trees was an unsustainable practice; it did not take into account the renewal of the resource.

\section{Quantities and distribution of the exploited products}

The total annual quantity of the exploited products was $1080.90 \mathrm{t}$ in which fruits collected were quantified for $725.62 \mathrm{t}$. These great quantities fruit were collected from 13 most popular fruit species (Figure 2). They were in order of importance of quantity: Ziziphus mauritiana (198.04 t), Adansonia digitata (180.13 t), Diospyros mespiliformis (120.88 t), Parkia biglobosa (118.55 t), Tamarindus indica $(4453$ t), Balanites aegyptiaca (18.73 t), Haematostaphis barteri $(18.31 \mathrm{t})$, Vitex doniana (4.59 t), Carissa edulis (4.52 t), Annona senegalensis (3.13 t), Ziziphus spina-christi (2.86 t), Ximenia americana $(2.79 \mathrm{t})$, and Detarium microcarpum (1.86 t). In the different zones, it appeared that Ziziphus 
mauritiana and Diospyros mespiliformis were the most exploited with a particularity in Mokolo and Roua-Zoulgo for both species. However, Adansonia digitata and Parkia biglobosa were heavily exploited respectively in Hina-Guider and Bourha-Kapsiki. The quantities of fruits collected varied between the zones and the exploited species. This variability was showed by calculating the variance that was significantly different $(\mathrm{P}=0.004)$. Local people, concerned with diversifying the sources of food products to cope with the lack of agricultural production, had developed an interest in the collection of non-timber forest products.

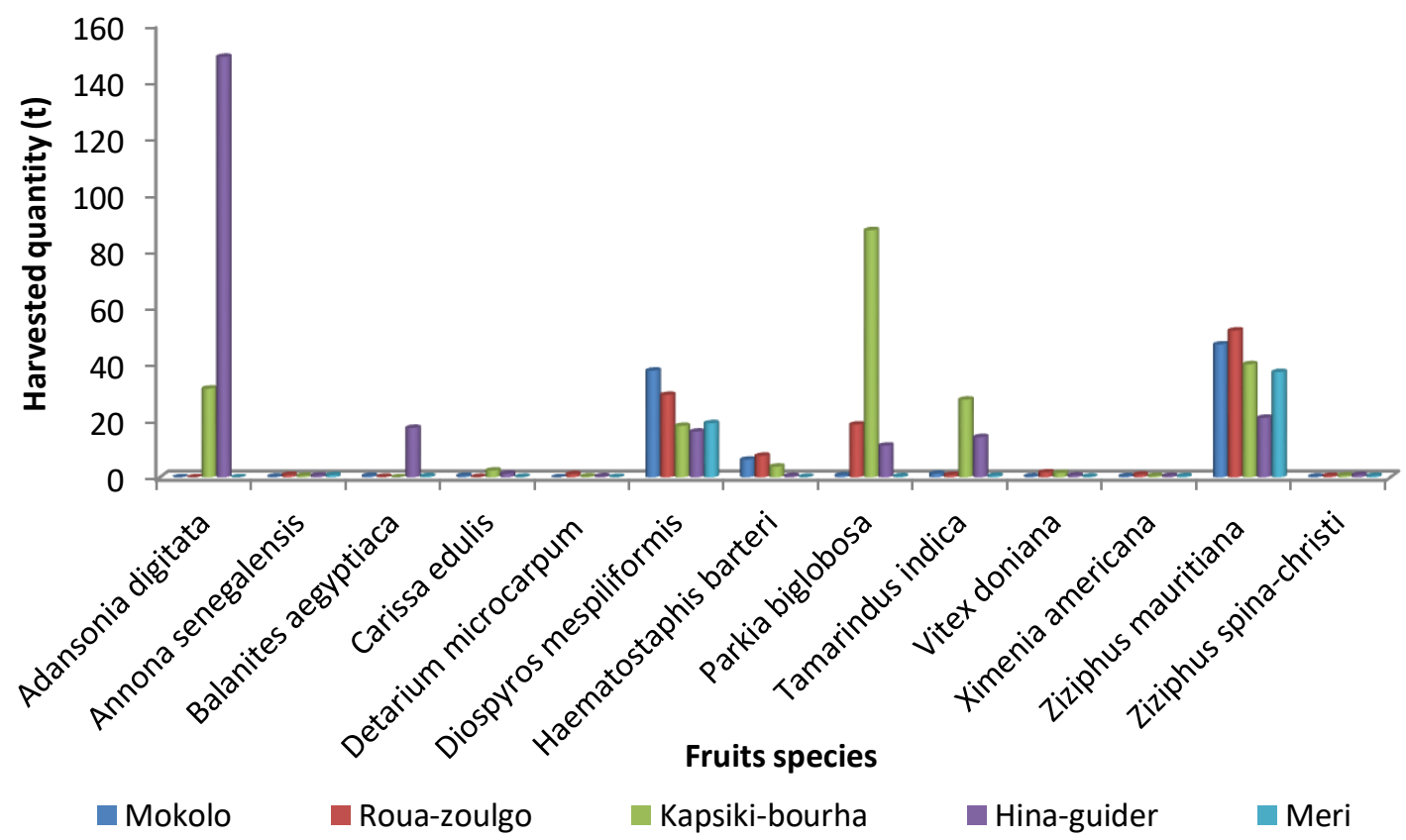

Figure 2. Annual quantities of fruits harvested.

The total annual quantity of leaves collected was 97.5 t. It was quantified from Adansonia digitata (58.26 t), Celtis integrifolia $(21.72 \mathrm{t})$, Balanites aegyptiaca (9.65 t), Vernonia amygdalina (5.89 t), Crateva adansoni (1.21 t) and Ficus cordata (0.77 t) (Tableau 2). Some species as Tamarindus indica, Ficus gnaphalocarpa, and Leptadenia hastada which leaves were most exploited and directly consumed in the household, the quantities were not evaluated. But these species products were most important and needed by the population of the Mounts Mandara region in their daily meal. The products (fruits, leaves, seeds) were consumed raw, cooked, transformed into juice, or in other traditional process. From the great quantities of leaves exploited, it could be concluded that those species were overexploited. The increasing of the population, the low agricultural production and poverty favored overexploitation of edible species. Something must be done for the sustainable management of the resource for the future.

Table 2: Quantities of leaves exploited in the Mount Mandara.

\begin{tabular}{|c|c|c|c|c|c|c|}
\hline \multirow[t]{2}{*}{ Specie } & \multicolumn{5}{|c|}{ Sampling zones } & \multirow[t]{2}{*}{ Total } \\
\hline & Mokolo & Roua-zoulgo & $\begin{array}{l}\text { Kapsiki- } \\
\text { bourha }\end{array}$ & Hina-guider & Meri & \\
\hline Adansonia digitata & 3.19 & 2.07 & 19.57 & 33.28 & 0.15 & 58.26 \\
\hline Balanites aegyptiaca & 0.07 & 0.51 & 0.78 & 7.45 & 0.84 & 9.65 \\
\hline Celtis integrifolia & 3.41 & 3.06 & 5.24 & 1.78 & 8.23 & 21.72 \\
\hline Crateva adansonii & 0.12 & 0.15 & 0.27 & 0.14 & 0.53 & 1.21 \\
\hline Ficus cordata & 0.05 & 0.14 & 0.01 & 0 & 0,57 & 0.77 \\
\hline Vernonia amygdalina & 3.57 & 0.47 & 1.02 & 0.83 & 0 & 5.89 \\
\hline
\end{tabular}

Only the flowers of Bombax costatum were quantified for the total annual quantity of $1.96 \mathrm{t}$. Flowers of Balanites aegyptiaca and that of Leptadenia hastada were also exploited mixed with the leaves and were not considered and not quantified.

Seeds were exploited on Parkia biglobosa and Balanites aegyptiaca; stones of Vitellaria paradoxa 
were also exploited (Table 3). The total annual quantity of seed of Parkia biglobosa (252 t) was significant. It was mostly collected in KapsikiBourha (119 t) zone where the density of Parkia was significant. It was situated in the frontier with Nigeria which had developed an industrial activities to transform the seeds of Parkia biglobosa. The quantities of seeds are variously used by the populations where a part is consumed locally and a certain quantity is sold. A significant proportion corresponding to $87.30 \%$ of the total production was sold on the markets. The consumption of seeds passed through transformation by a traditional process which consisted in making ferment seeds after scalding to remove the teguments. Fermentation took place under anaerobic conditions and lasted approximately 3 to 4 days. The fermented almonds gave a product aromatized with characteristic odor named "Dawa-dawa". After fermentation, Dawadawa was conditioned in limp sterilized beforehand to ensure a long conservation or shaped in pellets and dried.

The stone of Vitellaria paradoxa (2.09 t) was used for the extraction of butter, mostly in Hina-Guider and Kapsiki-Bourha zones.

Table 3: Annual quantities of seeds exploited in the Mount Mandara.

\begin{tabular}{|l|l|l|l|l|l|}
\hline \multirow{2}{*}{ Specie } & \multicolumn{5}{c|}{ Sampling zone } \\
\cline { 2 - 7 } & Mokolo & Roua-zoulgo & Kapsiki-Bourha & Hina-Guider & Meri \\
\hline Balanites aegyptiaca & 0,05 & 0,07 & 0,17 & 0,93 & 0,51 \\
\hline Parkia biglobosa & 97,5 & 33,75 & 119 & 0 & 0,75 \\
\hline Vitellaria paradoxa & 0 & 0,24 & 0,87 & 0,98 & 0 \\
\hline
\end{tabular}

The various collected products were used for consumption, sale and supply with varying proportions. The annual quantity of the products (fruits, leaves, flowers and seeds) was distributed in familial consumption $(30.33 \%)$; offers $(0.87 \%)$ to guests and relationships, and the main quantities (68.80\%) were marketed (Figure 3 ). The quantities of products were most important in Kapsiki-bourha $(361.87 \mathrm{t})$ and Hina-Guider $(281.07 \mathrm{t})$, and fewer in Meri $(72.27 \mathrm{t})$. The quantities of exploited products varied in each zone, this variability was showed by the calculation de variance $\mathrm{p}=0.0027$. According to the zones, the quantities consumed were between $27.59 \%$ in Roua-zoulgo and $32.69 \%$ to Hina-Guider.
The consumed quantities contributed to the daily meals of the poor rural households and permitted to diversify their food nutrition. The offered quantities were noted in all the zones between $1.63 \%$ in HinaGuider and $1.54 \%$ to Meri which were apparently fewer according to the number; but it was significant according to it social value in the maintaining of the family and friendly relationship. The diversity the plant products, their availability, permitted rural and urban to have food, to keep up relationship, and market for income to boost the household economy. Indeed, the populations were actively exploited plant products contributing to the degradation of the environment and failed the sustainable management.

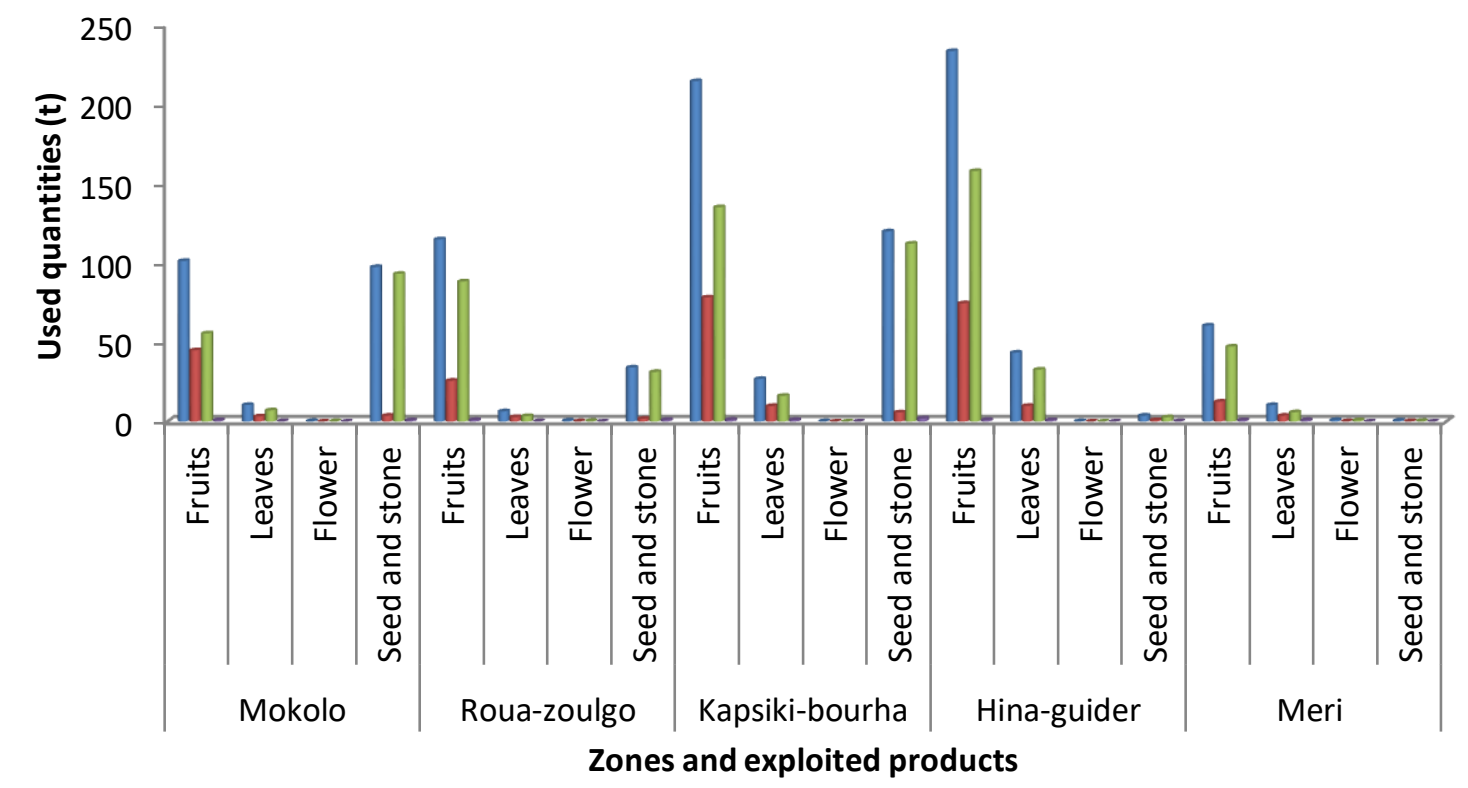

- Harvested quantities Consumed quantities Sale quantities O Offered quantities

Figure 3. Annual quantities of collected products and their used. 


\section{Marketing of the products exploited and income generated}

The total annual quantity of exploited products for selling was $791.21 \mathrm{t}$ in which: fruit accounted for $484.84 \mathrm{t}$, leaves represented $65.24 \mathrm{t}$, and seeds and stones was counted for $239.80 \mathrm{t}$, and flowers for 1.33 t. The variability of the sale quantities of the products was showed by the calculation of the variance highly significant $\mathrm{p} \leq 0.0000$. According to the zones, the sale quantities were as follows: $263.98 \mathrm{t}$ in KapsikiBourha, $193.64 \mathrm{t}$ in Hina-Guider, $123.41 \mathrm{t}$ in RouaZoulgo, in Mokolo they were $156.10 \mathrm{t}$ and Meri registered $54.08 \mathrm{t}$. The sale quantities were most important than those consumed by the people; it could demonstrate the people awareness to the wild products contributing to their well been. The marketing of large quantities of collected products made it possible to report an additive in the economy of the mounts Mandara people a substantial income of 60783975 francs CFA. The fruits were sold for 17542375 F CFA, the seeds yielded $36676900 \mathrm{~F}$ CFA, the contribution of the leaves was $5452820 \mathrm{~F}$ CFA and that of the flowers was $724880 \mathrm{~F}$ CFA, "dawa-dawa" brought, very popular, bring in a modest sum of 787000 CFA francs. According to the zones, the marketed products brougth: $23202325 \mathrm{~F}$ CFA in Kapsiki-Bourha, 19331250 F CFA in HinaGuider, $9150200 \mathrm{~F}$ CFA $\mathrm{t}$ in Roua-Zoulgo, in Mokolo they were 7127000 F CFA, and Meri registered $2173200 \mathrm{~F} \mathrm{CFA}$. The economic value and contribution of these products to the people's economy was very important. For some households, the annual aggregate income from the sale of the wild products was as important as the farm income. The combination of these revenues will enable farmers to cope with the food deficit.

\section{Marketing circuit of the exploited products}

According to the importance of the contribution of the exploited products in the household economy, the populations had developed a fluorescent trade around them (Figure 4). Products entering the marketing channel were: Parkia biglobosa and Balanites aegyptiaca seeds, fruit pulp and leaves of Adansonia digitata, fruits of Ziziphus mauritiana and leaves of Vernonia amygdalina. The chain was made up with $80 \%$ of women's actors who feed a complex commercial circuit. The actors involved were distributed as follows: operators / collectors; consumers; Retailers resellers, wholesalers, and exporters. Local collectors exploited these products in woodlands; few quantities were used for family consumption and some were sold. It could be sale at homes and rural periodic markets to local consumers and wholesalers and / or exporters. There were also local buyers who supplied wholesalers and exporters. Wholesalers and exporters came to weekly rural markets to buy at low prices to sell a bit more in the city. Once in the city, wholesalers delivered to resellers, retailers, consumers and exporters to earn a large gain. Resellers and retailers bought the products from wholesalers and settle either in a market or on the street in urban areas. The reseller could negotiate with the wholesaler to have the products he can sell to retailers and urban consumers. Exporters who bought from wholesalers or directly from local farmers send the products to neighboring Chad and Nigeria. This activity was informal and not well organized, but it allowed the actors and organizers of the circuit to make profits.

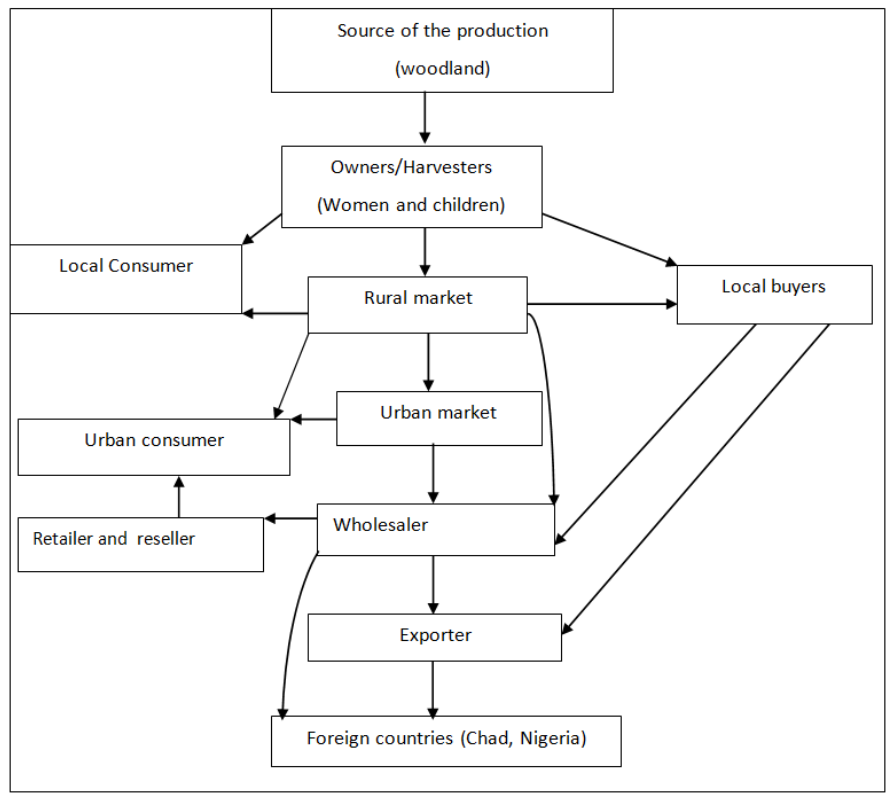

Figure 4. Description of trade-circuit of the exploited products. 


\section{Discussions \\ Diversity of wild edible plant products}

In the mounts Mandara, the edible plant products used were fruits, leaves, flowers, seeds, tubers, roots, bark, and stems. They entered the human diet and generated a substantial income to the household economy. These edible plant products were harvested from 61 species in which 54 were fruit species, 11 species produce leaves and / or flowers, and 4 species were exploited for their seeds. In Cameroon, Eyog Matig et al. (2006) listed 74 fruit species nationally, of which 24 species were similar to this study. Similarly, Mapongmetsem et al. (2012) had inventoried in the Sudano-Guinean and SudanoSahelian savannas of Cameroon 55 edible fruit species among which 30 species were similar to the present study. Djihounouck et al. (2018) in the zone of Kasa in Senegal inventoried 62 wild edible fruitspecies distributed in 31 families. Similar species were characteristic of Sahelian and Sudanian vegetation (Letouzey, 1985). The various edible products exploited constituted for the populations an important source of food which, made it possible to supplement their daily food need and a source of good and service. Maydell von (1981), Baumer (1985), Bergeret and Ribot (1990) and Mapongmetsem et al. (2012) who showed that the diversity of food products of plant origin exploited in the savannas contributed to supplement the food ration and represented a substantial source of income to ensure the well-being of the rural populations. In addition, they provided rural populations with the essential elements for their survival (Ambé, 2001, Mapongmetsem et al., 2008). In this zone, the fruits, leaves, flowers and seeds exploited were mostly eaten dry. For populations, drying was one of the methods of preserving food, given the long dry season. The same observation was made by Bergeret and Ribot (1990) and Mapongmetsem et al. (2012) on the products of the feeding trees in Sahelian countries and some wild edible fruits exploited in the SudanoSahelian zone of Cameroon.

The main methods of exploitation of the products practiced by the populations were: gathering and gathering on the tree, felling down trees and partial felling of trees. Exploitation activities were unsustainable practices; they were more intensive on the resource and represented an important ecological constraint. Similar methods of exploitation of nontimber forest products were described by Tchatat et al., (1999); Peters (1997); Shanley and Pierce (2002). These authors indicated that the intensity of exploitation depended on the domestic and / or commercial demand of the product. Indeed, the degree of commercialization of the product and access to the market or proximity to the market had an ecological consequence for the resource. The increasing of the demand of the edible plants products was consequently increased the pressure on the resource. In addition, the method of harvesting fruit trees was extremely harmful and typically unsustainable (Tchatat et al., 1999).

\section{Socio-economic value of exploited products}

The products of 19 species as fruits, leaves, flowers, seeds or stones were marketed. That was more than the number of 16 species with fruits marketed recorded in zone of Kasa in Senegal (Djihounouck et al., 2018). On the other hand, Dibong et al. (2011) and Betti et al (2016) respectively counted 25 wild fruit-bearing species of which the parts were marketed in the Douala markets, and 29 vegetable species sold in the Yaounde markets. The quantities of edible products used by the populations were becoming increasingly important; they varied according to the type of product. Populations were interested in exploiting non-timber edible forest products, which were chronologically well distributed and cover the whole year. The diversity of products, the size of the amount harvested and their availability throughout the year allowed rural farmers to fill the gap in agricultural production and ensure the daily food security of the family. The accessibility and the periods of availability of these species constituted the determining factors for their exploitation (Djihounouck et al., 2018).

The total annual quantity of the exploited products was $1080.90 \mathrm{t}$ in which: fruits were quantified for $725.62 \mathrm{t}$, leaves was $97.5 \mathrm{t}$, Flowers $1.96 \mathrm{t}$, and seeds or stone $255.82 \mathrm{t}$. The results of this study was more than those of Mapongmetsem et al. (2008) and (2012) who identified various types of products and estimated respectively $105.70 \mathrm{t}$ and $83 \mathrm{t}$ the amount of non-timber forest products used in home gardens in Sudano-Guinean zone of Cameroon and $18.694 \mathrm{t}$, the quantities of fruit harvested from 11 wild species in the high Guinean savanna and Sudano-Sahelian savannah areas. At the national level, Mbolo et al. 2002 quantified at $488.57 \mathrm{t}$ the production of Gnetum spp leaves in Cameroon's forest zone. But these authors noted that there was still no formal structure to determine the socio-economic value of non timber forest products in Cameroon. However, the distribution and availability of different non-timber forest products in the periods of the year allowed farmers to have at least one product during the year (Mapongmetsem et al., 2008). This availability of products made it possible to ensure family food security and the sale of the surplus made it possible to contribute to the family's monetary income (Tchatat et al., 2006, Betti et al., 2016; Djihounouck et al., 2018). 
To convene and satisfy the needs of local populations, the various products collected were part of different social and economic circuits. The amount of product exploited was distributed by farmers for family consumption, offers to friends and relatives and marketing for a substantial income in the economy. For the different products, the quantities marketed, consumed and offered depended on: the quantity collected. These results were different from those of Oekan (1990) who, studying the socioeconomic value of home gardens, showed that $60 \%$ of the products were consumed, the quantities offered and distributed as gifts to relatives, third and neighbors to strengthen the bonds of friendship and solidarity, represented $10 \%$. In addition, the results of Louanga's (2005) study showed that the total quantity produced in the South-West region amounts to $3991.1 \mathrm{~kg}$, that consumed to $1197.4 \mathrm{~kg}$ and sales to $2793.7 \mathrm{~kg}$. The difference between these results was due to the methodology adopted for data collection. The offer remained an important action of solidarity in the African society maintaining the family and friendly relationship. The donation of wild products to other members of the community was a very important aspect of economic life in rural Africa (Leliveld 1994, Chabal and Daloz 1999).

A great quantity of edible products: fruit $(484.84 \mathrm{t})$, leaves $(65.24 \mathrm{t})$, seeds $(239.80 \mathrm{t})$, and flowers $(1.33 \mathrm{t})$ was marketed. In the markets of southern Cameroon, large quantities of non-timber forest products were sold (Awono et al., 2000, Ayeni et al., 2003. The marketing of the exploited products gave a substantial income estimated at 60783975 CFA francs was reported, and the economic value and the contribution of these products to the economy of the population was very important. These results were less than those of Louanga (2005) study which estimated the annual income from the marketing of Gnetum at 2245928000 CFA francs, wild mangoes at 1152000 CFA francs, and Ayeni et al. (2003) estimated that the income generated by CFAF 4102124940 was the sale of non-timber forest products in the Takamanda Forest Reserve, Peltier et al. (2008) and Kabré et al. (2009) had estimated that the income from the exploitation of dungeons and the exploitation activities of forest was greater. These edible products were presented throughout the year and contributed effectively to the increase of farmers' incomes. The gathered fruits of these wild species constitute a significant share in the food of the local populations and strongly contribute to food safety for various layers of the populations and to the creation of richness (Djihounouck et al., 2018). However, the exploitation and marketing of non timber forest products as they occurred in Central Africa remained for some as a strategy to increase their income and not a guarantee of sustainable management of Non timber forest products or promotion of agroforestry practices (Mbolo, 2006).

These products, which were used in rural areas, were sold in urban markets in the three northern regions of Cameroon and their marketing crossed the country's borders. Similarly, the leaves of Gnetum africanum and G. bucholzianum (okok or eru) harvested in the Congo Basin were subject to regional and international trade. A large quantity of non-timber forest products was exported and allowed the development of a large market to neighboring countries and even to Europe (Mbolo et al., 2002, Ayeni et al., 2003, Tabuna, 2000 and 2007).

\section{Conclusion}

The study permitted to acknowledge the diversity of wild edible plants products in Mounts Mandara. A whole of 61 plants species belonging to 29 families were identified producing edible products. The populations exploit a wide variety of the products as: fruits, leaves, flowers, roots and / or tubers, bark, stems. Important quantities of edible products were exploited by the populations. These quantities were large and used for family consumption, sale to provide cash income and make offers. However, the quantities sold were most significant and permitted support the economics of the household and enable poor rural people to improve their well-being. As a result, the populations showed an interest in the exploitation of non-timber forest products. Farmers' concern was to diversify the sources of food and generate income to cope with inadequate agricultural production and environmental poverty. However, harvesting practices that were intensive and selective posed a significant threat to the species involved and were not sustainable. It was to be feared that in the coming years these resources will disappear.

\section{References}

1. Aboubakar, D., Sorto M, Mbayabe, L., Woin, N., Bourou, S. \& Gandebe, M. (2009). Commercialisation des fruits dans les savanes d'Afrique centrale. Communication au Colloque « Savane Africaines en développement : innover pour durer », 20-24 avril 2009, Garoua, Cameroun. Livre de résumé de la communication. $58 \mathrm{p}$.

2. Ambé G. A., 2001. Les fruits sauvages comestibles des savanes guinéennes de Côte-d'Ivoire : état de la connaissance par une population locale, les Malinké. Biotechnol. Agron. Soc. Environ, 5 (1) : 43-58.

3. Apema, R., Mozouloua, D. \& Madiapevo, SN (2010). Inventairepréliminaire des fruits sauvages comestibles vendus sur les marches de Bangui. Dans X. van der Burgt, J. van der Maesen, J.-M. Onana. (éds.). Systématique et conservation des plantes africaines (313-319). Kiew, Royal Botanical Garden, Royaume-Uni.

4. Apema, R., Mouzouloua, D. et Madiapevo, S.N., 2009. Inventaire préliminaire des fruits sauvages comestibles vendus sur les marchés de Bangui. In Systématique et conservation des plantes Africaines, eds. Van der Brugt, X., Van der Maesen, J. and Onana, J.M., Yaoundé, Cameroon. pp. 113-319. 
5. Aubé J., 1996. Etude pour favoriser le développement des produits forestiers non ligneux dans le cadre du Central African Regional Programme for the Environment (CARPE), Forestry Support Program, USAID, Washington, USA. 94 p.

6. Awono A., Ndoye O., Schreckenberg K., 2000. Commercialisation de Dacryodes edulis dans la zone forestière du Cameroun. In Kengue J., Kapseu C. et Kayem G. J. (eds.), 3ème séminaire international sur la valorisation du safoutier et autres oléagineux non conventionnels. Yaoundé, Cameroun, 3-5 octobre 2000. Presses Universitaire d'Afrique, Yaoundé. pp 400-417.

7. Ayeni, J. S. O., Besong S. B., Mdaihli M. and Ojong M., 2003. An Evaluation of the Exit Routes for non-timber forest product Within the TFR area. $19 \mathrm{p}$.

8. Bashir A. El Tahir and Jens Gebauer, 2004. Non-timber Forest Products: Opportunities and Constraints for Poverty Reduction in the Nuba Mountains, South Kordofan, Sudan. Conference on International Agricultural Research for Development. Deutscher Tropentag, Berlin, October 5-7, 2004. 10 p.

9. Baumer M., 1985. Arbres, arbustes et arbrisseaux nourriciers en Afrique occidentale. Enda tiers-monde, Dakar, série Etudes et Recherches, $\mathrm{n}^{\circ} 168-169-170.252$ p.

10. Belcher B. M., 2003. What isn't an NTFP. International Forestry Review, 5 (2): 161-168.

11. Bergeret A. et Ribot J. C., 1990. L'arbre nourricier en pays sahélien, éditions de la maison des sciences de l'homme, Paris. 237 p.

12. Bergonzini J. C., 2004. Changements climatiques, désertification, diversité biologique et forêts. $145 \mathrm{p}$.

13. Betti, JL, Ngankoué, CM, Dibong, SD \& Singa, AE (2016). Etude ethnobotanique des plantes alimentaires spontanées vendues dans les marchés de Yaoundé, Cameroun. International Journal of Biological and Chemical Sciences, 10 (4), 1678-1693.

14. Biloso M. A. et Lejoly J., 2006. Etude de l'exploitation et du marché des produits forestiers non ligneux à Kinshasa. Tropicultura, 24(3): 183-188.

15. Biloso M. A., 2008. Valorisation des produits forestiers non ligneux des plateaux de Batéké en périphérie de Kinshasa (RD Congo), Thèse de doctorat, Université Libre de Bruxelles. $250 \mathrm{p}$

16. Bourou, S., Ndiaye, F., Diouf, M., Diop, T. \& Van Damme, P. (2010). Tamarind (Tamarindus indica L.) parkland mycorrhizal potential within three agroecological zones of Senegal. Fruits, 65 (6), 377-385.

17. Chabal P., Daloz J. P., 1999. Africa works. Disorder as political instrument. James currey Publishers, Oxford. 143 p.

18. Debroux L., 1998. L'aménagement des forêts tropicales fondé sur la gestion des populations d'arbres: l'exemple de Moabi (Baillonella toxisperma Pierre) dans la forêt du Dja, Cameroun. Thèse Doctorat, Fac. Univ. Sciences Agronomiques, Gembloux, Belgique. 220 p.

19. Dibong S. D., Mpondo M. E., Ngoye A., Kwin M. F. et Betti J. L., 2011. Ethnobotanique et phytomédecine des plantes médicinales de Douala, Cameroun: Ethnobotany and phytomedicine of medicinal plants sold in Douala markets. Journal of Applied Biosciences, 37: 2496-2507.

20. Dieng, SD (2017). Evaluation des services écosystémiques fournis par Cordyla pinnata (Lepr. Ex A. Rich.) Milne-Redh., Detarium microcarpum Guill. Et Perr. et Detarium senegalense (J.F. Gmel.) :cas de la Forêt Classée de Patako et de ses environs (Centre-Ouest du Sénégal). Thèse de doctorat en Sciences de l'Environnement, Faculté des Sciences et Techniques, Université Cheikh Anta Diop de Dakar. 184 p.

21. Djihounouck Y., Diop D., Dieng S. D., Sane S., Bassène C., Mbaye S. M., Noba K., 2018. Diversité et importance socioeconomique des espèces fruitières sauvages comestibles en zone Kasa (Sud-Ouest du Sénégal). European Scientific Journal 14, (36), 352-376.
22. Donfack P., 1998. Végétation des jachères du Nord Cameroun. Typologie, diversité, dynamique, production. Thèse de doctorat d'Etat. Université de Yaoundé I. 184 p.

23. El-Siddig, K, Gunasena, HPM, Prasad, BA, Pushpakumara, DKNG, Ramana, KVR, Vijayand, P. \& Williams, JT (2006). Tamarind (Tamarindus indica L.), Br. Libr., Southampt. U.K. $126 \mathrm{p}$.

24. Eyog Matig O., Ndoye O., Kengue J. et Awono A. Editeurs, 2006. Les Fruitiers Forestiers Comestibles du Cameroun. Aspects botaniques et écologiques. 203 p.

25. Grangé et Lebart L., 1992. Traitements statistiques des enquêtes. Eds Dunod. 254 p.

26. Jiofack T, Fokunang C, Guedje N, Kemeuze V., Fongnzossie E., Nkongmeneck B. A., Mapongmetsem P. M., Tsabang N. 2010. Ethnobotanical uses of medicinals plants of two ethnoecological regions of Cameroon. International Journal of Medicine and Medical Sciences, 2 (3): 60-79.

27. Jiofack T., Ayissi I., Fokunang C., Guedje N., Kemeuze V, 2009. Ethnobotany and phytomedicine of the upper Nyong Valley forest in Cameroon. African Journal of Pharmacy and pharmacology, 3 (4): 144-150.

28. Kabré A. M., Somda J., Savadogo M. et Nianogo A. J., 2009. Bois-énergie au Burkina Faso: Consolidation des moyens d'existence durable (2006-2009). Ouagadougou, Burkina Faso : (eds) Bureau, UICN - Burkina Faso. 184 p.

29. Kouebou, C., Goygoy, F., Bourou, S., Djakissam, PK, Layla, H., Zenabou, G., Barbi, M., Vunyingah, M. \& Woin, N. (2013). Biodiversité et valeur alimentaire des fruits au Cameroun: observations préliminaires dans le Département de la Bénoué (Région du Nord). Journal of Applied Biosciences, 69, 5523-5533.

30. Laporte N. et Justice C., 2001. Monitoring of forest cover in Central Africa: why, what, how and when to monitor. CARPE Briefing Shet $\mathrm{N}^{\circ} 13$ CARPE / USAID. 143 p.

31. Leliveld A. H. M., 1994. Social security in developing countries: operation and dynamics of social security mechanisms in rural Swaziland. Research series 85 (Ph.D. Thesis). Timber gen institute, Amsterdam. 231 p.

32. Letouzey R., 1968. Etude phytogéographique du Cameroun. Eds. Paul Lechevalier. Paris. 511 p.

33. Letouzey R., 1985. Carte phytogéographique du Cameroun au $1 / 500.000 .1)$ Domaine sahélien et soudanien. IRA (Herbier National), Institut de la Carte Internationale de la Végétation. Toulouse. pp 1-26.

34. Louanga A. F. H., 2005. Etude des caractéristiques socioéconomiques des produits forestiers non-ligneux dans quatre localités frontalières du Nigeria. Mémoire du diplôme d'ingénieur des eaux, forets et chasses. Université de Dschang. $45 \mathrm{p}$.

35. Mapongmetsem P. M., Hamawa Y., Djeumene P., Maissele D., Kossebe C.F., Ndoum J. F., Nduryang J. B., Bebbe F., Bouba D., Wouldata S., Zigro L. et Barbi M., 2008. Valorisation des plantes alimentaires sauvages dans les savanes soudano-guinéennes du Cameroun. In Développement de l'Agro-Industrie et création des richesses. Actes Conférence Internationale. éds. Kapseu, C., Mbofung, C.M. et Amvam Zollo, P. H. Ngaoundéré, Cameroun. pp.5061.

36. Mapongmetsem P. M., Kapchie V. N., and Tefempa B.H., 2012. Diversity of local fruit trees and their contribution in sustaining the rural livelihood in the Northern Cameroon. Ethiopian Journal of Environmental Studies and Management, 5 (1). 32-46.

37. Marchal J. Y, 1980. Arbres et brousses du paysage soudanosahélien Dynamique des formations végétales au nord de la Haute Volta. Cah. O.R.S.T.O.ill., sér. Sci. Hum, vol. SFII, nofi, 3(1):137-169.

38. Maydell von H. J., 1990. Arbres et arbustes du Sahel. Leurs caractéristiques et leurs utilisations. Verlag Josef Margraf. $531 \mathrm{p}$

39. Mbaye, E. (2006). La cueillette en brousse : terroirs et filières $d u$ Gandoul. Fonctionnement, logiques, 
perspectives.... Thèse. Département de géographie, Université Cheikh Anta Diop de Dakar. 404 p.

40. Mbolo M., 1990. Germination et croissance de quelques espèces forestières du Sud Cameroun: exemple de quelques Légumineuses et Sapotacées. Thèse Doctorat 3è Cycle, Univ. Yaoundé. $268 \mathrm{p}$.

41. Mbolo M., 2006. Les perspectives de la certification des produits forestiers non ligneux en Afrique Centrale. Yaoundé, Cameroun: FAO, Rome, 29 p

42. Mbolo M., Walter S. et Lejeune J., 2002. La collecte et l'analyse des données statistiques sur les produits forestiers non ligneux une étude pilote au Cameroun, FAO, Rome, 139 p.

43. Ndoye O. et Perez M. R., 1997. Commerce Transfrontalier et Intégration Régionale en Afrique Centrale : cas des PFNLs. ORSTOM, Cahiers des Sciences Humaines. $56 \mathrm{p}$.

44. Ndoye O., 1995. The Market for non-Product in the Humid Forest Zone OF Cameroon and its Borders. Structure, Conduct, Performance and Policy Implications. Rapport non publié, CIFOR, Bogor, Indonesie. 104 p.

45. Ndoye O., Perez M. R. et Eyebe A., 1998. The Market of NTFP in the Humid Forest Zone of Cameroon, ODI rural development forestry network. $98 \mathrm{p}$.

46. Nkongmeneck B. A., 2007. Répertoire des plantes médicinales du Cameroun. Cameroon journal of ethnobotany. 1 (2): 36-46.

47. Ntoupka M., 1999. Impacts des perturbations anthropiques (pâturage, feu et coupe de bois) sur la dynamique de la savane arborée en zone soudano-sahélienne nord du Cameroun. Thèse de doctorat. Université Paul Valéry. 233 p.

48. Oekan S. A., 1990. Home garden in Java and their future development. In katleen Landauer \& Mark Brazil (éd.). Tropical home garden, UNU Bandung, Indonesia. pp. 69-79.

49. Okafor and Fernandes, 1987. Compound farms of Southeastern Nigeria. In: Agroforestry systems. pp. 153-168.

50. Onana, 1994. Ressources fourragères du Nord Cameroun: diversité, gestion et conservation. In: Actes de colloque sur la conservation des ressources phytogénétiques. Yaoundé, 1 (2): pp 166-180.
51. Peltier R., Duhem C. S. et Ichaou A., 2008. Valoriser les produits du palmier doum pour gérer durablement le système agroforestier d'une vallée sahélienne du Niger et éviter sa désertification, VertigO - La revue en sciences de l'environnement, 8 (1): 15 p.

52. Peters C.M., 1997. Exploitation des produits forestiers autres que le bois en forêt tropicale humide: manuel d'initiation écologique. Etude WWF. 49 p.

53. Shanley P. et Pierce A. R., 2002. Ecological issues. In: Shanley, P., Pierce, A.R., Laird, S.A. et Guillén, A. (eds). Tapping the Green market. Certification \& management of non-timber forest products. Earths can publications Ltd, London. pp 47-61.

54. Tabuna H., 1999. Le Marché des Produits Forestiers non Ligneux de l'Afrique Centrale en France et Belgique. Produits, Acteurs, Circuits de Distribution et Débouchés Actuels. CIFOR. 204 p.

55. Tabuna H., 2000. Evaluation des échanges des produits forestiers non ligneux entre l'Afrique subsaharienne et l'Europe, FAO, Rome. 91 p.

56. Tabuna H., 2007. Commerce sous régional et international des produits forestiers non ligneux alimentaires et des produits agricoles traditionnels en Afrique centrale : état des lieux et stratégie de développement. FAO: Rome $139 \mathrm{p}$

57. Tchatat M. et Ndoye O., 2006. Étude des produits forestiers non ligneux d'Afrique centrale: réalités et perspectives. Bois et forêts des tropiques, 288: 27-39.

58. Tchatat M., Balinga M., Vabi et Bidja R., 2002. Gestion durable des produits Forestiers non-ligneux au Cameroun: Etat biologique pour l'élaboration d'une stratégie nationale de gestion. Programme Tropenbos, Cameroun. 59 p.

59. Tchatat M., Ndoye O. et Nasi R., 1999. Produits forestiers autres que le bois d'œuvre (PFAB): Place dans l'aménagement durable des forêts humides d'Afrique centrale. Série FORAFRI, 18. CIRAD-Forêt, Montpellier, France. 95 p.

60. Westphal E. J., Embrechts J. D., Ferwerda H. A. E., van GilsMeeus H. J. W., Mutsaers J. M., Westphal-Stevels C., 1985. Cultures vivrières tropicales avec références spéciales au Cameroun. Pudoc Wageningen. 223 p. 